\title{
Calmodulin-Binding Proteins in Muscle: A Minireview on Nuclear Receptor Interacting Protein, Neurogranin, and Growth-Associated Protein 43
}

\author{
Fereshteh Moradi ${ }^{1}$, Emily N. Copeland ${ }^{2,3}$, Ryan W. Baranowski ${ }^{3,4}$, Aiden E. Scholey ${ }^{4}$, \\ Jeffrey A. Stuart ${ }^{1} \mathbb{D}$ and Val A. Fajardo $2,3,4, * \mathbb{D}$ \\ 1 Department of Biological Sciences, Brock University, St. Catharines, ON L2S 3A1, Canada; \\ fm15ta@brocku.ca (F.M.); jstuart@brocku.ca (J.A.S.) \\ 2 Centre for Neuroscience, Brock University, St. Catharines, ON L2S 3A1, Canada; ec15wf@brocku.ca \\ 3 Centre for Bone and Muscle Health, Brock University, St. Catharines, ON L2S 3A1, Canada; \\ rb15xz@brocku.ca \\ 4 Department of Kinesiology, Brock University, St. Catharines, ON L2S 3A1, Canada; as15js@brocku.ca \\ * Correspondence: vfajardo@brocku.ca
}

Received: 16 December 2019; Accepted: 31 January 2020; Published: 4 February 2020

\begin{abstract}
Calmodulin $(\mathrm{CaM})$ is an important $\mathrm{Ca}^{2+}$-sensing protein with numerous downstream targets that are either CaM-dependant or CaM-regulated. In muscle, CaM-dependent proteins, which are critical regulators of dynamic $\mathrm{Ca}^{2+}$ handling and contractility, include calcineurin (CaN), CaM-dependant kinase II (CaMKII), ryanodine receptor (RyR), and dihydropyridine receptor (DHPR). CaM-regulated targets include genes associated with oxidative metabolism, muscle plasticity, and repair. Despite its importance in muscle, the regulation of $\mathrm{CaM}-$ particularly its availability to bind to and activate downstream targets-is an emerging area of research. In this minireview, we discuss recent studies revealing the importance of small IQ motif proteins that bind to CaM to either facilitate (nuclear receptor interacting protein; NRIP) its activation of downstream targets, or sequester (neurogranin, $\mathrm{Ng}$; and growth-associated protein 43, GAP43) CaM away from their downstream targets. Specifically, we discuss recent studies that have begun uncovering the physiological roles of NRIP, Ng, and GAP43 in skeletal and cardiac muscle, thereby highlighting the importance of endogenously expressed CaM-binding proteins and their regulation of $\mathrm{CaM}$ in muscle.
\end{abstract}

Keywords: calcineurin; CaMKII; neurogranin; GAP43; neuromodulin; NRIP; IQ-motif

\section{Introduction}

Composed of two canonical EF-hand lobes, calmodulin (CaM) binds up to four $\mathrm{Ca}^{2+}$ ions. Upon $\mathrm{Ca}^{2+}$ binding, the EF-hand motifs undergo a conformational alteration, exposing hydrophobic sidechains to the surface and thereby engaging in hydrophobic protein-protein interactions with numerous downstream targets that include enzymes and ion channels [1]. In muscle, CaM can bind to and activate several proteins that regulate gene expression and $\mathrm{Ca}^{2+}$ handling, ultimately influencing muscle contractility, metabolism, and plasticity [2,3]. These include but are not limited to CaM-dependant kinase II (CaMKII), calcineurin $(\mathrm{CaN})$, ryanodine receptor (RyR), and dihydropyridine receptor (DHPR) [3-7]. Despite its established importance in muscle, the regulation of CaM-specifically its ability to bind to and activate its downstream targets-is emerging as an important area of research.

The IQ motif is a loosely conserved domain that begins with isoleucine (I) and glutamine (Q) and generally consists of IQXXXRGXXXR, where the X represents non-conserved residues. With over 900 
Pfam entries, the IQ motif is widely distributed, and for a more comprehensive review, readers are referred to Bahler et al. [8]. Proteins that contain the IQ motif are able to bind to $\mathrm{CaM}$ in its $\mathrm{Ca}^{2+}$-free (apo-CaM) and/or $\mathrm{Ca}^{2+}$-bound states. Therefore, these IQ motif proteins may regulate CaM availability at low and high $\mathrm{Ca}^{2+}$ levels by sequestering CaM away from its downstream targets, or facilitating its interaction with other proteins by concentrating $\mathrm{CaM}$ in specifically localized pools. In this minireview, we discuss recent research revealing the physiological roles of three small IQ motif proteins in skeletal and cardiac muscle: nuclear receptor interacting protein (NRIP), growth-associated protein 43 (GAP43), and neurogranin $(\mathrm{Ng})$.

\section{Nuclear Receptor Interacting Protein}

NRIP is an androgen receptor (AR)-interacting protein that has an IQ motif enabling CaM binding [9]. Its interaction with $\mathrm{CaM}$ is $\mathrm{Ca}^{2+}$ dependent, as $\mathrm{CaM}$ binding is diminished in the presence of the $\mathrm{Ca}^{2+}$ chelator EGTA [10]. NRIP is highly expressed in cardiac and skeletal muscle where it is specifically localized at the Z-disc $[9,11]$. In skeletal muscle, NRIP co-localizes with CaN, which is a $\mathrm{Ca}^{2+} / \mathrm{CaM}$-dependant phosphatase that regulates gene expression by dephosphorylating nuclear factor of activated T cells (NFAT), leading to their subsequent nuclear entry. NFAT is a multigene family of inducible nuclear transcription factors containing five members: NFATc1, NFATc2, NFATc3, NFATc4, and NFAT5 [12]. All NFAT family members, except NFAT5, are regulated by CaN. Recently, Chen et al. [9] generated Nrip-knockout mice and demonstrated that, in the absence of NRIP, NFAT phosphorylation was enhanced, thereby revealing the importance of NRIP for calcineurin activation in rodent skeletal muscle. In addition, CaMKII is a $\mathrm{Ca}^{2+} / \mathrm{CaM}$-dependent serine/threonine protein kinase that, upon CaM binding, can exhibit autonomous enzyme activity via intramolecular autophosphorylation [7]. Chen et al. found that CaMKII phosphorylation was reduced, suggesting that both CaN and CaMKII activation were impaired in the absence of NRIP. To explain this finding, co-immunoprecipitation experiments demonstrated reduced CaM-CaN and CaM-CaMKII binding in muscles from Nrip-null mice compared with the wild-type (WT), which highlights the role of NRIP in facilitating CaM binding and activation of CaN and CaMKII [9].

Together, CaMKII and CaN can work synergistically to increase the expression of genes associated with oxidative metabolism. CaMKII acts to increase myocyte enhancer factor 2 (MEF2) nuclear activity by phosphorylating its repressor, the class-II histone deacetylases (HDAC; -4, -5, and 7), leading to its subsequent export out of the nucleus [13-15]. In addition, CaMKII activity is also required for MEF2 binding to its target genes in skeletal muscle [16]. Along with dephosphorylated NFAT (via CaN), activated MEF2 (via CaMKII) promotes the expression of genes largely expressed in oxidative muscle fibre types, such as myosin heavy chain I, myoglobin, slow troponin, and peroxisome proliferator-activated receptor gamma coactivator 1-alpha (PGC1- $\alpha)[7,17,18]$. Not surprisingly, Chen et al. showed that muscles from Nrip-null mice had a reduction in the proportion of slow-oxidative fibres and a concomitant increase in the fast-glycolytic fibres. Associated with this finding, the authors also showed that fatigue resistance was significantly impaired in Nrip-knockout isolated muscles and also in Nrip-knockout mice subjected to exhaustive treadmill running [9].

While an overall reduction in the oxidative phenotype can contribute to increased muscle fatigability, Chen et al. [9] also reported reductions in total sarcoplasmic reticulum (SR) $\mathrm{Ca}^{2+}$ content and release, without any changes in the expression of the $\mathrm{RyR} \mathrm{Ca}^{2+}$ channels or the sarco(endo)plasmic reticulum $\mathrm{Ca}^{2+}$-ATPase (SERCA) pump. A reduction in releasable $\mathrm{Ca}^{2+}$ also translates into reduced force production and fatigue resistance in the Nrip-knockout mice. During normal excitation contraction coupling (ECC) in skeletal muscle, membrane depolarization sensed by the DHPR leads to RyR opening and $\mathrm{Ca}^{2+}$ release via a physical connection between DHPR and RyR. Both DHPR and RyR are regulated by CaM binding; however, modulation of skeletal muscle ECC via CaM is complex. Previous studies have shown that $\mathrm{Ca}^{2+} / \mathrm{CaM}$ binding to the IQ motif of skeletal muscle DHPR is involved in $\mathrm{Ca}^{2+}$-dependent inactivation of DHPR $\mathrm{Ca}^{2+}$ currents $[19,20]$. In contrast, mutations in the IQ motif of DHPR reduces $\mathrm{Ca}^{2+}$ currents [21]. Further, under low $\mathrm{Ca}^{2+}$ conditions, apo-CaM binds to RyR and 
acts to increase RyR channel openness, whereas under high $\mathrm{Ca}^{2+}$ conditions, $\mathrm{Ca}^{2+}-\mathrm{CaM}$ binds to RyR and partially lowers RyR open probability $[22,23]$. Altogether, these results suggest that CaM binding to DHPR and RyR could have multiple roles in modulating $\mathrm{Ca}^{2+}$ release. Given the role of NRIP in facilitating CaM binding with its downstream targets, the reductions in $\mathrm{SR} \mathrm{Ca}^{2+}$ release observed with genetic Nrip deletion [9] may highlight a role for NRIP in stimulating $\mathrm{Ca}^{2+}$ release via CaM binding with DHPR and/or RyR. It is also possible that NRIP's activation of CaMKII is critical for $\mathrm{Ca}^{2+}$ release, since CaMKII can phosphorylate RyR1 to increase its open probability [24]. A reduction in CaMKII activation may also contribute to reduced total $\mathrm{SR} \mathrm{Ca}^{2+}$ content, since it is well known that CaMKII can phosphorylate and inactivate phospholamban (PLN)—a negative regulator of the SERCA pump [25]. Thus, in the absence of altered SERCA and RyR protein levels, as reported by Chen et al. [9], Nrip-null mice may exhibit lowered SERCA pump activation and RyR channel open probability leading to reduced SR total $\mathrm{Ca}^{2+}$ content and release.

With respect to muscle disease, NRIP expression was previously found to be lowered in the affected muscles of patients living with limb girdle muscular dystrophy [26]. Given the importance of NRIP in CaN and CaMKII activation and overall muscle contractility and fatigability, it is plausible that this downregulation of NRIP represents a maladaptive response in limb girdle muscular dystrophy. Indeed, Chen et al. [9] demonstrated that silencing Nrip expression in C2C12 cells attenuated myoblast fusion and differentiation, and that Nrip-null mice had delayed muscle regeneration after cardiotoxin injection. This is not surprising since $\mathrm{CaN}$ has long been linked with myogenic differentiation and fusion in vitro and muscle regeneration in vivo by stimulating the expression of proteins such as myogenin, interleukin-4, and stabilin-2 [27-34]. The latter is a phosphatidylserine receptor that plays an important role in promoting myoblast fusion and is regulated by CaN/NFAT signalling [29].

In cardiac muscle, recent evidence suggests that NRIP has a role in maintaining normal myocardial function, since muscle-specific Nrip-null mice displayed impaired contractility with a lowered left ventricular (LV) ejection fraction [11]. Yang et al. further demonstrated that isolated cardiomyocytes from Nrip-null mice had reduced rates of shortening and re-lengthening, which were associated with significant reductions in the peak $\mathrm{Ca}^{2+}$ amplitude and rate of $\mathrm{Ca}^{2+}$ decay. While these findings reveal the importance of NRIP in both systolic and diastolic function, no alterations in CaMKII nor NFAT phosphorylation were observed, and therefore unlike skeletal muscle, the impairments in cardiac contractility were not associated with changes in CaMKII or CaN activation. Rather, the cardiac muscle weakness and $\mathrm{Ca}^{2+}$ dysregulation were linked to an impairment in mitochondrial respiration and increase in mitochondrial reactive oxygen species (ROS) production. Yang et al. found that scavenging mitochondrial ROS with mitoTEMPO restored cardiac contractile function in the Nrip-null mice. Further, the Nrip-null mice also exhibited a cardiomyopathic phenotype that likely contributed to the impairments in cardiac contractility, including cardiac hypertrophy, ventricular dilation, aberrant sarcomeric (i.e., widening of Z-disk and narrowing of the I-band) and mitochondrial (i.e., cristae disarrangement) structure. Finally, Yang et al. reported significant reductions in NRIP expression in human and rodent failing hearts, which indicates that NRIP is not only important for normal cardiac function but could serve as a potential therapeutic target for heart failure.

\section{Neurogranin}

Neurogranin $(\mathrm{Ng})$ is a small IQ motif containing protein that is particularly enriched in neuronal cells in the cerebral cortex, hippocampus, and striatum, where it is thought to either bind to and sequester CaM away from its downstream targets [35,36], or concentrate CaM and facilitate CaM activation of downstream targets in specialized localizations [37,38]. $\mathrm{Ng}$ is capable of binding to apo-CaM and $\mathrm{Ca}^{2+-} \mathrm{CaM}$; when bound to $\mathrm{CaM}, \mathrm{Ng}$ reduces its affinity for $\mathrm{Ca}^{2+}$ while also enhancing the rate of $\mathrm{Ca}^{2+}$ dissociation $[39,40]$. Together, these findings would suggest that $\mathrm{Ng}$ has a negative role in CaM activation. $\mathrm{Ng}$ was once thought to be a neuronal specific protein; however, we have recently discovered that $\mathrm{Ng}$ is expressed in mammalian skeletal muscle (rodent and human), and is particularly abundant in slow-oxidative muscle fibers [28]. Using C2C12 cells, our results showed that silencing 
$\mathrm{Ng}$ increased CaM-CaN binding-indicative of a role for $\mathrm{Ng}$ in sequestering CaM in these muscle cells. We also observed a significant reduction in NFAT phosphorylation and a significant increase in utrophin expression, which is a cytoskeletal protein controlled by CaN signalling [41]. Associated with enhanced $\mathrm{CaN}$ signalling, knocking down $\mathrm{Ng}$ also led to a significant enhancement of myoblast fusion and myogenic differentiation [28]. Given the role of $\mathrm{CaN}$ in muscle regeneration [27-34], it will be important to determine whether reducing $\mathrm{Ng}$ expression and increasing $\mathrm{CaM}-\mathrm{CaN}$ binding in mice may enhance muscle regeneration in vivo. To date, the regulation of $\mathrm{Ng}$ on CaMKII signalling has not been investigated. In contrast with $\mathrm{CaN}$, evidence in neuronal cells indicates that $\mathrm{Ng}$ concentrates CaM in dendritic spines, thereby activating CaMKII and long-term potentiation [42]. Thus, it will be important to determine whether $\mathrm{Ng}$ activates or inhibits CaMKII in rodent skeletal muscle. Finally, the enrichment of $\mathrm{Ng}$ in slow-oxidative muscle fibres [28] warrants the investigation of $\mathrm{Ng}$ and its physiological role in cardiac muscle where it may regulate $\mathrm{CaN}, \mathrm{CaMKII}$, and $\mathrm{Ca}^{2+}$ handling.

\section{Growth-Associated Protein 43}

GAP43, also known as neuromodulin, was discovered 30 years ago in synaptosomal plasma membranes of rat brain and is now known for its role in neuronal development and regeneration [43]. Similar to Ng, GAP43 contains an IQ domain that facilitates binding to CaM and is capable of binding to apo-CaM and $\mathrm{Ca}^{2+}-\mathrm{CaM}$. GAP43 acts as a CaM "sponge" that binds to CaM and sequesters it away from its downstream targets [43]. Once believed to be a neuron-specific protein, recent evidence suggests that GAP43 is expressed in skeletal muscle [43-45], where it regulates dynamic handling of intracellular $\mathrm{Ca}^{2+}$. In 2016, Caprara et al. [45] examined the physiological role of GAP43 in skeletal muscle with Gap43-knockout mice. These mice showed low survival rates beyond weaning, a reduced adult body weight, decreased muscle strength, and an altered myofiber ultrastructure with no significant changes in the markers of satellite cell activation and myogenesis. Consistent with its putative role in dynamic $\mathrm{Ca}^{2+}$ regulation, myotubes isolated from surviving Gap43-null mice displayed an increased amplitude of $\mathrm{Ca}^{2+}$ release in response to depolarization ( $\mathrm{KCl}$ treatment) and caffeine. The emerging hypothesis from Caprara et al. [45] was that GAP43 regulates downstream CaM interactions with RyR and DHPR to modulate $\mathrm{Ca}^{2+}$ channel opening; that is, in the absence of GAP43, CaM readily binds to RyR and DHPR leading to their activation. Indeed, treating the Gap43-null myotubes with W7 CaM inhibitor reduced the $\mathrm{Ca}^{2+}$ amplitude [45]. Though neither CaN or CaMKII activation have been directly examined in muscles from Gap43-null mice, Caprara et al. [45] did not observe any effects of Gap 43 deletion (heterozygous or homozygous) on myoblast fusion and differentiation in primary myoblasts. Given the role of $\mathrm{CaN}$ in regulating myoblast fusion and myogenic differentiation [27,28], these results suggest that GAP43 may have less of a role in regulating $\mathrm{CaN}$ and is rather more important in regulating free intracellular $\mathrm{Ca}^{2+}$ during muscle contraction and relaxation. Future studies that examine whether genetic deletion of Gap 43 alters fibre type distribution and fatigue resistance, similar to that conducted with Nrip-null mice [9], will provide more insight towards the role of GAP43 in regulating CaM activation of $\mathrm{CaN}$ and CaMKII. In addition, given the importance of $\mathrm{Ca}^{2+}$ regulation and CaM signalling in cardiomyocytes, investigations focusing on the potential role of GAP43 in cardiac muscle will be of interest.

\section{Physiological Significance}

By uncovering the role of these endogenously expressed proteins that either facilitate CaM binding with its downstream targets (NRIP, Figure 1A) or sequester it away from its downstream targets $(\mathrm{Ng}$ and GAP43, Figure 1B), a new area of research has emerged in the field of muscle physiology. With the abundance of experimental support demonstrating the physiological importance of CaM-dependent and CaM-regulated proteins (i.e., CaN, CaMKII, RyR, and DHPR) in muscle, we can anticipate that these CaM-binding proteins, and those yet to be uncovered and characterized, could have several physiological implications. 


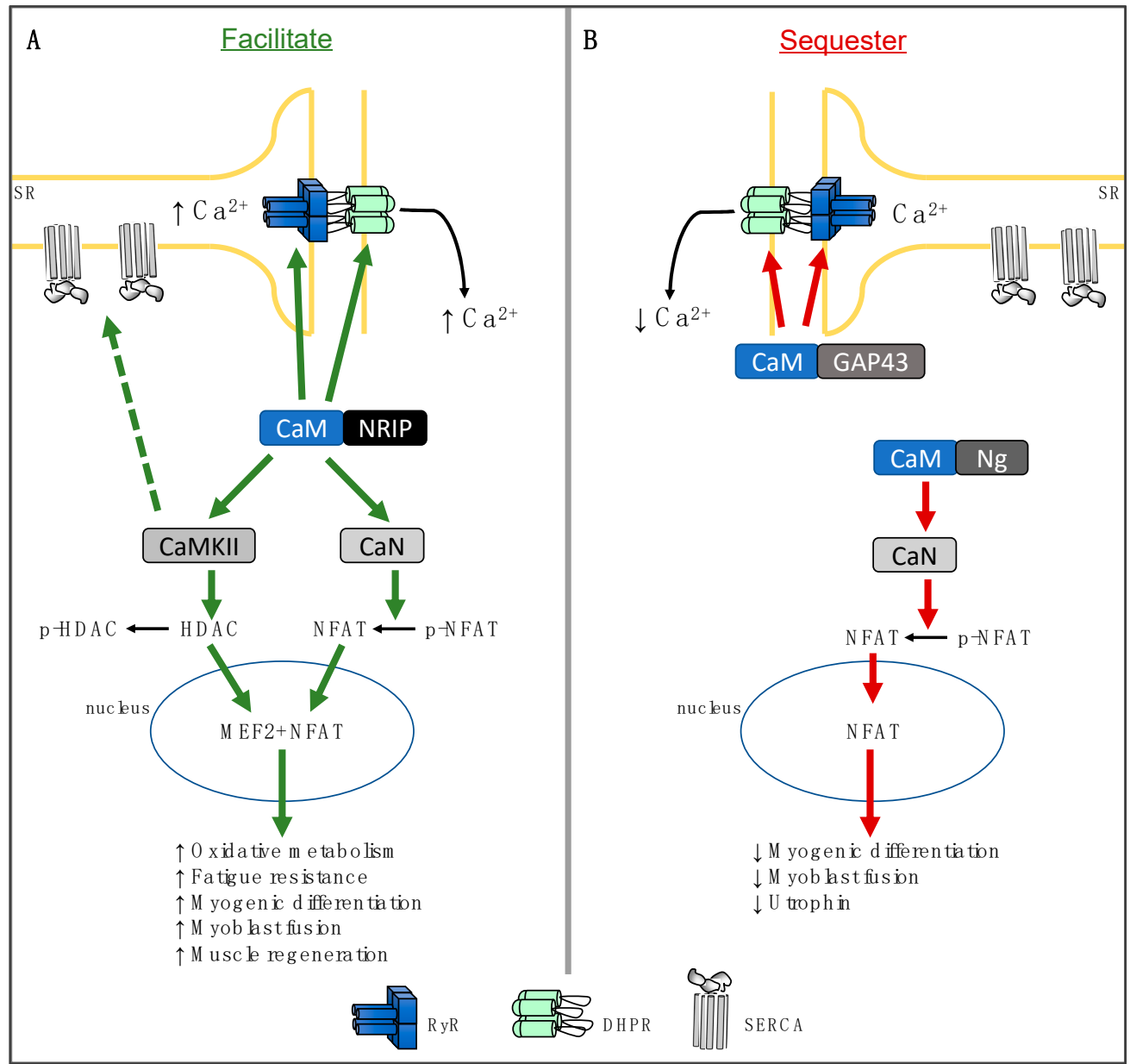

Figure 1. Simplified scheme of the physiological roles of calmodulin (CaM)-binding proteins, nuclear receptor interacting protein (NRIP), neurogranin $(\mathrm{Ng})$, and growth-associated protein 43 (GAP43) in skeletal muscle. (A) CaM-binding proteins that facilitate CaM binding with its downstream targets leads to their subsequent activation (green arrows). Recent evidence has revealed a role for NRIP in facilitating CaM binding to ryanodine receptor (RyR) and dihydropyridine receptor (DHPR), thereby contributing to increased sarcoplasmic reticulum (SR) $\mathrm{Ca}^{2+}$ release [9]. NRIP also facilitates CaM binding and activation of CaMKII and CaN. Activated CaMKII phosphorylates class-II histone deacetylases (HDACs), thereby activating myocyte enhancer factor 2 (MEF2). CaN dephosphorylates nuclear factor of activated T-cell (NFAT), leading to its nuclear entry. Together MEF2 and NFAT increase the expression of genes associated with oxidative fibre type, fatigability, myogenic differentiation, myoblast fusion, and muscle regeneration [9]. The dashed green arrow illustrates the hypothetical scenario by which enhanced CaM-dependent kinase II (CaMKII) activation with NRIP can lead to increased SERCA-mediated $\mathrm{Ca}^{2+}$ uptake, thereby enhancing total SR $\mathrm{Ca}^{2+}$ potentially by phosphorylating phospholamban (not shown here) and relieving its inhibition of SERCA. (B) CaM binding proteins that sequester CaM away from its downstream targets lead to a subsequent reduction in their activation (red arrows). $\mathrm{Ng}$ binds to $\mathrm{CaM}$ and prevents its binding to $\mathrm{CaN}$, leading to a reduction in myogenic differentiation, myoblast fusion, and utrophin expression [28]. GAP43 binds to CaM and prevents it from binding to RyR and DHPR, thereby reducing SR Ca ${ }^{2+}$ release. The role of NRIP in maintaining normal cardiac function [11] is not shown here.

For example, previous research has shown that activating $\mathrm{CaN}$ in rodent skeletal muscle via overexpression of its constitutively active form promotes the slow-oxidative phenotype, leading to a reduction in fatigability [46]. Genetic deletion of calsarcin-2, an endogenously expressed CaN inhibitor particularly enriched in fast-twitch glycolytic fibres, also leads to a shift toward slow-oxidative 
fibres and a concomitant increase in fatigue resistance [47]. Alternatively, inhibiting calcineurin signalling pharmacologically with cyclosporine or FK506 treatment [6], or by overexpressing its endogenously expressed inhibitor, regulator of calcineurin 1 (RCAN1) [48], promotes a switch toward the fast-glycolytic fibre type, leading to an enhancement in fatigability. Thus, altering CaN activation upstream via CaM regulation could have important implications in muscle fibre type composition and endurance. Indeed, the binding of NRIP to CaM facilitates CaM/CaN and CaM/CaMKII activation, leading to a switch toward the slow-oxidative fibre type and fatigue resistance [9]. However, the roles of CaM sequestering proteins ( $\mathrm{Ng}$ and GAP43) on muscle fibre type composition and endurance have not yet been examined. Further, both $\mathrm{CaN}$ and CaMKII are activated with chronic endurance training and contribute to the benefits associated with regular exercise (i.e., mitochondrial biogenesis) $[49,50]$. Studying whether these CaM regulatory proteins potentiate or reduce the benefits associated with chronic endurance training would have physiological implications for exercise performance and health.

It is known that the type I fibres are more insulin sensitive and are better at oxidizing fat compared to their type II glycolytic counterparts. Transgenic overexpression of the constitutively active form of $\mathrm{CaN}$ in mice improves insulin-stimulated glucose uptake, enhances fatty acid oxidation, and protects against high fat diet-induced glucose intolerance [51]. Recent evidence also implicates $\mathrm{CaN}$ in the activation of whole-body thermogenesis [52]. Genetic deletion of Rcan1 led to a significant increase in muscle sarcolipin (SLN) expression, which mediates muscle-based thermogenesis by uncoupling SERCA-catalyzed $\mathrm{Ca}^{2+}$ transport [53,54]. Rcan1-null mice also had increased expression of uncoupling protein 1 (UCP-1) in adipose tissue, which is a mitochondrial uncoupler well-known to have implications for diet-induced obesity $[55,56]$. In turn, when Rcan1-null were fed a high fat diet, they experienced less weight and were more glucose tolerant when compared with WT mice [52]. Therefore, it will be of interest to determine whether regulating $\mathrm{CaN}$ signalling via upstream control of CaM availability would have a similar impact on diet-induced obesity and glucose handling as those observed with other endogenous regulators of $\mathrm{CaN}$, such as RCAN1.

Duchenne muscular dystrophy (DMD) is a severe X-linked muscle-wasting condition caused by an absence of the functional dystrophin protein that primarily affects the fast-glycolytic fibres $[57,58]$. This is partly because oxidative fibres express more utrophin-a dystrophin homolog [41]. The importance of regulating $\mathrm{CaM}$ and its downstream activation of $\mathrm{CaN}$ and CaMKII have been made evident with $m d x$ mice (DMD mouse model) overexpressing a synthetic CaM binding protein that sequesters CaM and limits its availability [59]. These $m d x$ mice exhibited impairments in both CaN and CaMKII signalling, and not surprisingly, the CaMBP overexpressing $m d x$ muscles displayed a worsened dystrophic pathology with reductions in utrophin expression [60]. In addition to its effects on utrophin, CaN's activation of muscle regeneration is also important for muscular dystrophy [61]. When CaN signalling was blocked with cyclosporine $\mathrm{A}, m d x$ muscles had fewer centrally nucleated fibres (marker of regeneration), more endomysial fibrosis and mononuclear cell infiltration, and were $30 \%-35 \%$ weaker compared with the vehicle control [62]. SLN also functions as a CaN activator in muscle in addition to uncoupling the SERCA pump [63]. Genetic deletion of $\operatorname{Sln}$ in $m d x$ mice led to impairments in CaN signalling, thereby reducing utrophin and stabilin-2 expression and exacerbating muscle weakness in $m d x$ mice [64]. Collectively, these studies demonstrate the importance of CaN and CaMKII in mitigating a dystrophic pathology. Indeed, there are other muscle diseases in which activating these CaM-dependent proteins could lead to physiological benefits, including myotonic dystrophy type 1 [65] and centronuclear myopathy [66]. Therefore, the regulation of CaM availability will have a significant physiological impact on a number of muscle myopathies.

There is also some evidence suggesting that $\mathrm{CaN}$ may promote skeletal muscle hypertrophy; however, there is considerable discrepancy [67]. Chronic administration of cyclosporine A or FK506 in mice inhibits $\mathrm{CaN}$ activation while preventing the fast-to-slow fiber type transformation that occurs during functional overload of the plantaris muscle [68]. In some cases, this has also been shown to prevent the increase in muscle mass and individual fiber cross-sectional area commonly observed in the overloaded plantaris $[69,70]$. However, there have also been studies that have reported no such 
effect of $\mathrm{CaN}$ on muscle mass (for a review see Reference [67]). Indeed, the role of CaN in stimulating muscle hypertrophy is complicated due to the fact that $\mathrm{CaN}$ also promotes the slow-oxidative fibre type that is inherently smaller than fast-glycolytic fibres. Nonetheless, $\mathrm{CaN}$ is well-known to play a role in myoblast fusion $[27,29]$, which could enhance muscle regeneration and myofiber size [71,72].

In contrast with skeletal muscle, it is well known that $\mathrm{CaN}$ contributes to pathological but not physiological cardiac hypertrophy [73,74]. For example, mice lacking calsarcin-1, an endogenous calcineurin inhibitor found specifically in slow-oxidative fibres, had an augmented hypertrophic response to thoracic aortic banding, but not in response to exercise [74]. These findings raise a potential dichotomy, whereby activating CaN may benefit skeletal muscle performance and regeneration but may lead to pathological cardiac hypertrophy. In this respect, NRIP has been shown to activate CaN and enhance fatigue resistance in skeletal muscle [9]; however, NRIP was not shown to have a role in CaN signalling in cardiac muscle [11]. In fact, genetic deletion of Nrip in cardiac muscle led to muscle weakness, cardiac hypertrophy, and ventricle dilation [11]. Further, $\mathrm{CaN}$ activation has been shown to protect against dilated cardiomyopathy [75]. Together these findings highlight the importance of examining the potential physiological roles of these endogenously expressed CaM-binding proteins in both cardiac and skeletal muscle.

\section{Conclusions}

Though only recently emerging as a field of study, CaM regulation via endogenously expressed IQ motif proteins, such as NRIP, GAP43 and Ng, may have important implications for skeletal and cardiac muscle health. We anticipate that future studies of CaM regulation will uncover novel mediators/regulators of $\mathrm{CaN}$ and CaMKII signalling and intracellular $\mathrm{Ca}^{2+}$ dynamics, which could potentially be exploited to enhance muscle performance and treat conditions such as obesity, type 2 diabetes, and muscular dystrophy. However, a potential dichotomy may exist when activating $\mathrm{CaN}$ in skeletal muscle vs. cardiac muscle, where pathological hypertrophy in the latter could occur. Thus, it is important to investigate the effects of these CaM-binding proteins in both skeletal and cardiac muscle.

Author Contributions: Conceptualization, F.M. and V.A.F.; writing—original draft preparation, F.M. and V.A.F.; writing-review and editing, F.M., E.N.C., R.W.B., A.E.S., J.A.S. and V.A.F.; all authors have read and agreed to the published version of the manuscript.

Funding: This research was funded by an NSERC Discovery Grant to V.A.F., grant number RGPIN 2019-05833.

Acknowledgments: We thank the Brock University Library Open Access Fund for supporting the publication fee associated with this manuscript.

Conflicts of Interest: The authors declare no conflict of interest.

\section{Abbreviations}

$\begin{array}{ll}\text { AID } & \text { Autoinhibitory domain } \\ \text { CaM } & \text { Calmodulin } \\ \text { CaMKII } & \text { Calmodulin dependent kinase II } \\ \text { CsA } & \text { Cyclosporine A } \\ \text { CNM } & \text { Centronuclear myopathy } \\ \text { CaMBP } & \text { Calmodulin-binding protein } \\ \text { DHPR } & \text { Dihydropyridine receptors } \\ \text { DMD } & \text { Duchenne muscular dystrophy } \\ \text { DM1 } & \text { Myotonic dystrophy type 1 } \\ \text { GAP43 } & \text { Neuron-growth-associated protein 43 } \\ \text { MEF2 } & \text { Myocyte enhancer factor 2 } \\ \text { NFAT } & \text { Nuclear factor of activated T-cells } \\ \text { NRIP } & \text { Nuclear receptor interacting protein } \\ \text { Ng } & \text { Neurogranin } \\ \text { PGC1- } & \text { Peroxisome proliferator-activated receptor gamma coactivator 1-alpha }\end{array}$




$\begin{array}{ll}\text { PLN } & \text { Phospholamban } \\ \text { RyR } & \text { Ryanodine receptor } \\ \text { SR } & \text { Sarcoplasmic reticulum } \\ \text { ROS } & \text { Reactive oxygen species } \\ \text { RCAN1 } & \text { Regulator of calcineurin1 } \\ \text { SERCA } & \text { Sarco(endo)plasmic reticulum } \mathrm{Ca}^{2+} \text { ATPase } \\ \text { SLN } & \text { Sarcolipin } \\ \text { UCP1 } & \text { Uncoupling protein } 1\end{array}$

\section{References}

1. Ikura, M.; Ames, J.B. Genetic polymorphism and protein conformational plasticity in the calmodulin superfamily: Two ways to promote multifunctionality. Proc. Natl. Acad. Sci. USA 2006, 103, 1159-1164. [CrossRef]

2. Ojuka, E.O.; Goyaram, V.; Smith, J.A. The role of CaMKII in regulating GLUT4 expression in skeletal muscle. Am. J. Physiol. Endocrinol. Metab. 2012, 303, E322-E331. [CrossRef]

3. Tavi, P.; Westerblad, $\mathrm{H}$. The role of in vivo $\mathrm{Ca}(2)(+)$ signals acting on $\mathrm{Ca}(2)(+)$-calmodulin-dependent proteins for skeletal muscle plasticity. J. Physiol. 2011, 589, 5021-5031. [CrossRef]

4. Stull, J.T.; Kamm, K.E.; Vandenboom, R. Myosin light chain kinase and the role of myosin light chain phosphorylation in skeletal muscle. Arch. Biochem. Biophys. 2011, 510, 120-128. [CrossRef]

5. Olson, E.N.; Williams, R.S. Remodeling muscles with calcineurin. BioEssays 2000, 22, 510-519. [CrossRef]

6. Michel, R.N.; Chin, E.R.; Chakkalakal, J.V.; Eibl, J.K.; Jasmin, B.J. Ca2+/calmodulin-based signalling in the regulation of the muscle fibre phenotype and its therapeutic potential via modulation of utrophin A and myostatin expression. Appl. Physiol. Nutr. Metab. 2007, 32, 921-929. [CrossRef] [PubMed]

7. Chin, E.R. Role of Ca2+/calmodulin-dependent kinases in skeletal muscle plasticity. J. Appl. Physiol. 2005, 99, 414-423. [CrossRef] [PubMed]

8. Bahler, M.; Rhoads, A. Calmodulin signaling via the IQ motif. FEBS Lett. 2002, 513, 107-113. [CrossRef]

9. Chen, H.H.; Chen, W.P.; Yan, W.L.; Huang, Y.C.; Chang, S.W.; Fu, W.M.; Su, M.J.; Yu, I.S.; Tsai, T.C.; Yan, Y.T.; et al. NRIP is newly identified as a Z-disc protein, activating calmodulin signaling for skeletal muscle contraction and regeneration. J. Cell Sci. 2015, 128, 4196-4209. [CrossRef]

10. Chang, S.W.; Tsao, Y.P.; Lin, C.Y.; Chen, S.L. NRIP, a novel calmodulin binding protein, activates calcineurin to dephosphorylate human papillomavirus E2 protein. J. Virol. 2011, 85, 6750-6763. [CrossRef]

11. Yang, K.C.; Chuang, K.W.; Yen, W.S.; Lin, S.Y.; Chen, H.H.; Chang, S.W.; Lin, Y.S.; Wu, W.L.; Tsao, Y.P.; Chen, W.P.; et al. Deficiency of nuclear receptor interaction protein leads to cardiomyopathy by disrupting sarcomere structure and mitochondrial respiration. J. Mol. Cell Cardiol. 2019, 137, 9-24. [CrossRef] [PubMed]

12. Shen, T.; Liu, Y.; Cseresnyes, Z.; Hawkins, A.; Randall, W.R.; Schneider, M.F. Activity- and calcineurin-independent nuclear shuttling of NFATc1, but not NFATc3, in adult skeletal muscle fibers. Mol. Biol. Cell 2006, 17, 1570-1582. [CrossRef] [PubMed]

13. Zhang, T.; Kohlhaas, M.; Backs, J.; Mishra, S.; Phillips, W.; Dybkova, N.; Chang, S.; Ling, H.; Bers, D.M.; Maier, L.S.; et al. CaMKIIdelta isoforms differentially affect calcium handling but similarly regulate HDAC/MEF2 transcriptional responses. J. Biol. Chem. 2007, 282, 35078-35087. [CrossRef] [PubMed]

14. Potthoff, M.J.; Olson, E.N. MEF2: A central regulator of diverse developmental programs. Dev. 2007, 134, 4131-4140. [CrossRef] [PubMed]

15. Potthoff, M.J.; Wu, H.; Arnold, M.A.; Shelton, J.M.; Backs, J.; McAnally, J.; Richardson, J.A.; Bassel-Duby, R.; Olson, E.N. Histone deacetylase degradation and MEF2 activation promote the formation of slow-twitch myofibers. J. Clin. Investig. 2007, 117, 2459-2467. [CrossRef]

16. Smith, J.A.; Kohn, T.A.; Chetty, A.K.; Ojuka, E.O. CaMK activation during exercise is required for histone hyperacetylation and MEF2A binding at the MEF2 site on the Glut4 gene. Am. J. Physiol. Endocrinol. Metab. 2008, 295, E698-E704. [CrossRef]

17. Angus, L.M.; Chakkalakal, J.V.; Mejat, A.; Eibl, J.K.; Belanger, G.; Megeney, L.A.; Chin, E.R.; Schaeffer, L.; Michel, R.N.; Jasmin, B.J. Calcineurin-NFAT signaling, together with GABP and peroxisome PGC-1[1], drives utrophin gene expression at the neuromuscular junction. Am. J. Physiol. Cell Physiol. 2005, 289, C908-C917. [CrossRef] 
18. Jiang, L.Q.; Garcia-Roves, P.M.; de Castro Barbosa, T.; Zierath, J.R. Constitutively active calcineurin in skeletal muscle increases endurance performance and mitochondrial respiratory capacity. Am. J. Physiol. Endocrinol. Metab. 2010, 298, E8-E16. [CrossRef]

19. Pate, P.; Mochca-Morales, J.; Wu, Y.; Zhang, J.Z.; Rodney, G.G.; Serysheva, I.I.; Williams, B.Y.; Anderson, M.E.; Hamilton, S.L. Determinants for calmodulin binding on voltage-dependent Ca2+ channels. J. Biol. Chem. 2000, 275, 39786-39792. [CrossRef]

20. Stroffekova, K. Ca2+/CaM-dependent inactivation of the skeletal muscle L-type Ca2+ channel (Cav1.1). Pflugers Arch. 2008, 455, 873-884. [CrossRef]

21. Stroffekova, K. The IQ motif is crucial for Cav1.1 function. J. Biomed. Biotechnol. 2011, 2011, 504649. [CrossRef] [PubMed]

22. Yamaguchi, N.; Xin, C.; Meissner, G. Identification of apocalmodulin and Ca2+-calmodulin regulatory domain in skeletal muscle Ca2+ release channel, ryanodine receptor. J. Biol. Chem. 2001, 276, 22579-22585. [CrossRef] [PubMed]

23. Samso, M.; Wagenknecht, T. Apocalmodulin and Ca2+-calmodulin bind to neighboring locations on the ryanodine receptor. J. Biol. Chem. 2002, 277, 1349-1353. [CrossRef] [PubMed]

24. Lanner, J.T.; Georgiou, D.K.; Joshi, A.D.; Hamilton, S.L. Ryanodine receptors: Structure, expression, molecular details, and function in calcium release. Cold Spring Harb. Perspect. Biol. 2010, 2, a003996. [CrossRef]

25. MacLennan, D.H.; Kranias, E.G. Phospholamban: A crucial regulator of cardiac contractility. Nat. Rev. Mol. Cell Biol. 2003, 4, 566-577. [CrossRef]

26. Zhang, Y.; Ye, J.; Chen, D.; Zhao, X.; Xiao, X.; Tai, S.; Yang, W.; Zhu, D. Differential expression profiling between the relative normal and dystrophic muscle tissues from the same LGMD patient. J. Transl. Med. 2006, 4, 53. [CrossRef]

27. Van der Velden, J.L.; Schols, A.M.; Willems, J.; Kelders, M.C.; Langen, R.C. Glycogen synthase kinase 3 suppresses myogenic differentiation through negative regulation of NFATc3. J. Biol. Chem. 2008, 283, 358-366. [CrossRef]

28. Fajardo, V.A.; Watson, C.J.F.; Bott, K.N.; Moradi, F.; Maddalena, L.A.; Bellissimo, C.A.; Turner, K.D.; Peters, S.J.; LeBlanc, P.J.; MacNeil, A.J.; et al. Neurogranin is expressed in mammalian skeletal muscle and inhibits calcineurin signaling and myoblast fusion. Am. J. Physiol. Cell Physiol. 2019, 317, C1025-C1033. [CrossRef]

29. Park, S.Y.; Yun, Y.; Lim, J.S.; Kim, M.J.; Kim, S.Y.; Kim, J.E.; Kim, I.S. Stabilin-2 modulates the efficiency of myoblast fusion during myogenic differentiation and muscle regeneration. Nat. Commun. 2016, 7, 10871. [CrossRef]

30. Sakuma, K.; Nishikawa, J.; Nakao, R.; Watanabe, K.; Totsuka, T.; Nakano, H.; Sano, M.; Yasuhara, M. Calcineurin is a potent regulator for skeletal muscle regeneration by association with NFATc1 and GATA-2. Acta Neuropathol. 2003, 105, 271-280. [CrossRef]

31. Stupka, N.; Schertzer, J.D.; Bassel-Duby, R.; Olson, E.N.; Lynch, G.S. Calcineurin-A alpha activation enhances the structure and function of regenerating muscles after myotoxic injury. Am. J. Physiol. Regul. Integr. Comp. Physiol. 2007, 293, R686-R694. [CrossRef]

32. Horsley, V.; Friday, B.B.; Matteson, S.; Kegley, K.M.; Gephart, J.; Pavlath, G.K. Regulation of the growth of multinucleated muscle cells by an NFATC2-dependent pathway. J. Cell Biol. 2001, 153, 329-338. [CrossRef] [PubMed]

33. Horsley, V.; Jansen, K.M.; Mills, S.T.; Pavlath, G.K. IL-4 acts as a myoblast recruitment factor during mammalian muscle growth. Cell 2003, 113, 483-494. [CrossRef]

34. Horsley, V.; Pavlath, G.K. Prostaglandin F2(alpha) stimulates growth of skeletal muscle cells via an NFATC2-dependent pathway. J. Cell Biol. 2003, 161, 111-118. [CrossRef]

35. Martzen, M.R.; Slemmon, J.R. The dendritic peptide neurogranin can regulate a calmodulin-dependent target. J. Neurochem. 1995, 64, 92-100. [CrossRef] [PubMed]

36. Krucker, T.; Siggins, G.R.; McNamara, R.K.; Lindsley, K.A.; Dao, A.; Allison, D.W.; De Lecea, L.; Lovenberg, T.W.; Sutcliffe, J.G.; Gerendasy, D.D. Targeted disruption of RC3 reveals a calmodulin-based mechanism for regulating metaplasticity in the hippocampus. J. Neurosci. 2002, 22, 5525-5535. [CrossRef]

37. Petersen, A.; Gerges, N.Z. Neurogranin regulates CaM dynamics at dendritic spines. Sci. Rep. 2015, 5, 11135. [CrossRef] 
38. Pak, J.H.; Huang, F.L.; Li, J.; Balschun, D.; Reymann, K.G.; Chiang, C.; Westphal, H.; Huang, K.P. Involvement of neurogranin in the modulation of calcium/calmodulin-dependent protein kinase II, synaptic plasticity, and spatial learning: A study with knockout mice. Proc. Natl. Acad. Sci. USA 2000, 97, 11232-11237. [CrossRef]

39. Hoffman, L.; Chandrasekar, A.; Wang, X.; Putkey, J.A.; Waxham, M.N. Neurogranin alters the structure and calcium binding properties of calmodulin. J. Biol. Chem. 2014, 289, 14644-14655. [CrossRef]

40. Gaertner, T.R.; Putkey, J.A.; Waxham, M.N. RC3/Neurogranin and Ca2+/calmodulin-dependent protein kinase II produce opposing effects on the affinity of calmodulin for calcium. J. Biol. Chem. 2004, 279, 39374-39382. [CrossRef]

41. Chakkalakal, J.V.; Stocksley, M.A.; Harrison, M.A.; Angus, L.M.; Deschenes-Furry, J.; St-Pierre, S.; Megeney, L.A.; Chin, E.R.; Michel, R.N.; Jasmin, B.J. Expression of utrophin A mRNA correlates with the oxidative capacity of skeletal muscle fiber types and is regulated by calcineurin/NFAT signaling. Proc. Natl. Acad. Sci. USA 2003, 100, 7791-7796. [CrossRef]

42. Zhong, L.; Gerges, N.Z. Neurogranin targets calmodulin and lowers the threshold for the induction of long-term potentiation. PLoS ONE 2012, 7, e41275. [CrossRef]

43. Guarnieri, S.; Morabito, C.; Paolini, C.; Boncompagni, S.; Pilla, R.; Fano-Illic, G.; Mariggio, M.A. Growth associated protein 43 is expressed in skeletal muscle fibers and is localized in proximity of mitochondria and calcium release units. PLoS ONE 2013, 8, e53267. [CrossRef]

44. Caprara, G.A.; Perni, S.; Morabito, C.; Mariggio, M.A.; Guarnieri, S. Specific association of growth-associated protein 43 with calcium release units in skeletal muscles of lower vertebrates. Eur. J. Histochem. 2014, 58, 2453. [CrossRef]

45. Caprara, G.A.; Morabito, C.; Perni, S.; Navarra, R.; Guarnieri, S.; Mariggio, M.A. Evidence for Altered Ca(2+) Handling in Growth Associated Protein 43-Knockout Skeletal Muscle. Front. Physiol. 2016, 7, 493. [CrossRef]

46. Long, Y.C.; Glund, S.; Garcia-Roves, P.M.; Zierath, J.R. Calcineurin regulates skeletal muscle metabolism via coordinated changes in gene expression. J. Biol. Chem. 2007, 282, 1607-1614. [CrossRef]

47. Frey, N.; Frank, D.; Lippl, S.; Kuhn, C.; Kogler, H.; Barrientos, T.; Rohr, C.; Will, R.; Muller, O.J.; Weiler, H.; et al. Calsarcin-2 deficiency increases exercise capacity in mice through calcineurin/NFAT activation. J. Clin. Investig. 2008, 118, 3598-3608. [CrossRef]

48. Oh, M.; Rybkin, I.I.; Copeland, V.; Czubryt, M.P.; Shelton, J.M.; van Rooij, E.; Richardson, J.A.; Hill, J.A.; De Windt, L.J.; Bassel-Duby, R.; et al. Calcineurin is necessary for the maintenance but not embryonic development of slow muscle fibers. Mol. Cell Biol. 2005, 25, 6629-6638. [CrossRef]

49. Pattanakuhar, S.; Pongchaidecha, A.; Chattipakorn, N.; Chattipakorn, S.C. The effect of exercise on skeletal muscle fibre type distribution in obesity: From cellular levels to clinical application. Obes. Res. Clin. Pract. 2017, 11, 112-132. [CrossRef]

50. Wu, H.; Rothermel, B.; Kanatous, S.; Rosenberg, P.; Naya, F.J.; Shelton, J.M.; Hutcheson, K.A.; DiMaio, J.M.; Olson, E.N.; Bassel-Duby, R.; et al. Activation of MEF2 by muscle activity is mediated through a calcineurin-dependent pathway. EMBO J. 2001, 20, 6414-6423. [CrossRef]

51. Ryder, J.W.; Bassel-Duby, R.; Olson, E.N.; Zierath, J.R. Skeletal muscle reprogramming by activation of calcineurin improves insulin action on metabolic pathways. J. Biol. Chem. 2003, 278, 44298-44304. [CrossRef] [PubMed]

52. Rotter, D.; Peiris, H.; Grinsfelder, D.B.; Martin, A.M.; Burchfield, J.; Parra, V.; Hull, C.; Morales, C.R.; Jessup, C.F.; Matusica, D.; et al. Regulator of Calcineurin 1 helps coordinate whole-body metabolism and thermogenesis. EMBO Rep. 2018, 19. [CrossRef] [PubMed]

53. Bombardier, E.; Smith, I.C.; Gamu, D.; Fajardo, V.A.; Vigna, C.; Sayer, R.A.; Gupta, S.C.; Bal, N.C.; Periasamy, M.; Tupling, A.R. Sarcolipin trumps beta-adrenergic receptor signaling as the favored mechanism for muscle-based diet-induced thermogenesis. FASEB J. 2013, 27, 3871-3878. [CrossRef] [PubMed]

54. Bombardier, E.; Smith, I.C.; Vigna, C.; Fajardo, V.A.; Tupling, A.R. Ablation of sarcolipin decreases the energy requirements for $\mathrm{Ca} 2+$ transport by sarco(endo)plasmic reticulum Ca2+-ATPases in resting skeletal muscle. FEBS Lett. 2013, 587, 1687-1692. [CrossRef]

55. Cannon, B.; Nedergaard, J. Brown adipose tissue: Function and physiological significance. Physiol. Rev. 2004, 84, 277-359. [CrossRef]

56. Fuller-Jackson, J.P.; Henry, B.A. Adipose and skeletal muscle thermogenesis: Studies from large animals. J. Endocrinol. 2018, 237, R99-R115. [CrossRef] 
57. Consolino, C.M.; Brooks, S.V. Susceptibility to sarcomere injury induced by single stretches of maximally activated muscles of mdx mice. J. Appl. Physiol. 2004, 96, 633-638. [CrossRef]

58. Webster, C.; Silberstein, L.; Hays, A.P.; Blau, H.M. Fast muscle fibers are preferentially affected in Duchenne muscular dystrophy. Cell 1988, 52, 503-513. [CrossRef]

59. Wang, J.; Campos, B.; Jamieson, G.A., Jr.; Kaetzel, M.A.; Dedman, J.R. Functional elimination of calmodulin within the nucleus by targeted expression of an inhibitor peptide. J. Biol. Chem. 1995, 270, 30245-30248. [CrossRef]

60. Chakkalakal, J.V.; Michel, S.A.; Chin, E.R.; Michel, R.N.; Jasmin, B.J. Targeted inhibition of Ca2+/calmodulin signaling exacerbates the dystrophic phenotype in mdx mouse muscle. Hum. Mol. Genet. 2006, 15, 1423-1435. [CrossRef]

61. Stupka, N.; Schertzer, J.D.; Bassel-Duby, R.; Olson, E.N.; Lynch, G.S. Stimulation of calcineurin Aalpha activity attenuates muscle pathophysiology in mdx dystrophic mice. Am. J. Physiol. Regul. Integr. Comp. Physiol. 2008, 294, R983-R992. [CrossRef] [PubMed]

62. Stupka, N.; Gregorevic, P.; Plant, D.R.; Lynch, G.S. The calcineurin signal transduction pathway is essential for successful muscle regeneration in mdx dystrophic mice. Acta Neuropathol. 2004, 107, 299-310. [CrossRef] [PubMed]

63. Maurya, S.K.; Bal, N.C.; Sopariwala, D.H.; Pant, M.; Rowland, L.A.; Shaikh, S.A.; Periasamy, M. Sarcolipin Is a Key Determinant of the Basal Metabolic Rate, and Its Overexpression Enhances Energy Expenditure and Resistance against Diet-induced Obesity. J. Biol. Chem. 2015, 290, 10840-10849. [CrossRef] [PubMed]

64. Fajardo, V.A.; Chambers, P.J.; Juracic, E.S.; Rietze, B.A.; Gamu, D.; Bellissimo, C.; Kwon, F.; Quadrilatero, J.; Russell Tupling, A. Sarcolipin deletion in mdx mice impairs calcineurin signalling and worsens dystrophic pathology. Hum. Mol. Genet. 2018. [CrossRef]

65. Ravel-Chapuis, A.; Belanger, G.; Cote, J.; Michel, R.N.; Jasmin, B.J. Misregulation of calcium-handling proteins promotes hyperactivation of calcineurin-NFAT signaling in skeletal muscle of DM1 mice. Hum. Mol. Genet. 2017, 26, 2192-2206. [CrossRef]

66. Fajardo, V.A.; Gamu, D.; Mitchell, A.; Bloemberg, D.; Bombardier, E.; Chambers, P.J.; Bellissimo, C.; Quadrilatero, J.; Tupling, A.R. Sarcolipin deletion exacerbates soleus muscle atrophy and weakness in phospholamban overexpressing mice. PLoS ONE 2017, 12, e0173708. [CrossRef]

67. Schiaffino, S.; Serrano, A. Calcineurin signaling and neural control of skeletal muscle fiber type and size. Trends Pharmacol. Sci. 2002, 23, 569-575. [CrossRef]

68. Chin, E.R.; Olson, E.N.; Richardson, J.A.; Yang, Q.; Humphries, C.; Shelton, J.M.; Wu, H.; Zhu, W.; Bassel-Duby, R.; Williams, R.S. A calcineurin-dependent transcriptional pathway controls skeletal muscle fiber type. Genes Dev. 1998, 12, 2499-2509. [CrossRef]

69. Dunn, S.E.; Burns, J.L.; Michel, R.N. Calcineurin is required for skeletal muscle hypertrophy. J. Biol. Chem. 1999, 274, 21908-21912. [CrossRef]

70. Dunn, S.E.; Chin, E.R.; Michel, R.N. Matching of calcineurin activity to upstream effectors is critical for skeletal muscle fiber growth. J. Cell Biol. 2000, 151, 663-672. [CrossRef]

71. Allen, D.L.; Roy, R.R.; Edgerton, V.R. Myonuclear domains in muscle adaptation and disease. Muscle Nerve 1999, 22, 1350-1360. [CrossRef]

72. Kurgan, N.; Whitley, K.C.; Maddalena, L.A.; Moradi, F.; Stoikos, J.; Hamstra, S.I.; Rubie, E.A.; Kumar, M.; Roy, B.D.; Woodgett, J.R.; et al. A Low-Therapeutic Dose of Lithium Inhibits GSK3 and Enhances Myoblast Fusion in C2C12 Cells. Cells 2019, 8. [CrossRef] [PubMed]

73. Wilkins, B.J.; Dai, Y.S.; Bueno, O.F.; Parsons, S.A.; Xu, J.; Plank, D.M.; Jones, F.; Kimball, T.R.; Molkentin, J.D. Calcineurin/NFAT coupling participates in pathological, but not physiological, cardiac hypertrophy. Circ. Res. 2004, 94, 110-118. [CrossRef] [PubMed] 
74. Frey, N.; Barrientos, T.; Shelton, J.M.; Frank, D.; Rutten, H.; Gehring, D.; Kuhn, C.; Lutz, M.; Rothermel, B.; Bassel-Duby, R.; et al. Mice lacking calsarcin-1 are sensitized to calcineurin signaling and show accelerated cardiomyopathy in response to pathological biomechanical stress. Nat. Med. 2004, 10, 1336-1343. [CrossRef]

75. Heineke, J.; Wollert, K.C.; Osinska, H.; Sargent, M.A.; York, A.J.; Robbins, J.; Molkentin, J.D. Calcineurin protects the heart in a murine model of dilated cardiomyopathy. J. Mol. Cell Cardiol. 2010, 48, 1080-1087. [CrossRef]

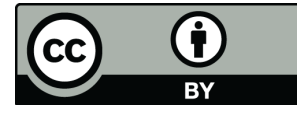

(C) 2020 by the authors. Licensee MDPI, Basel, Switzerland. This article is an open access article distributed under the terms and conditions of the Creative Commons Attribution (CC BY) license (http://creativecommons.org/licenses/by/4.0/). 